Supplement of Biogeosciences, 14, 4341-4354, 2017

https://doi.org/10.5194/bg-14-4341-2017-supplement

(C) Author(s) 2017. This work is distributed under

the Creative Commons Attribution 3.0 License.

(c) (1)

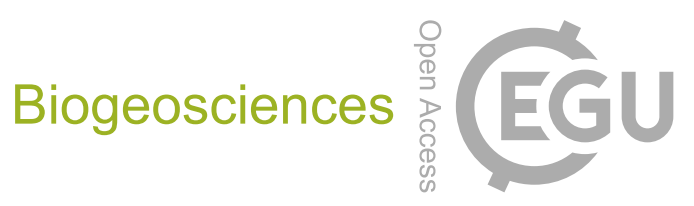

Supplement of

Soil respiration across a permafrost transition zone: spatial structure and environmental correlates

James C. Stegen et al.

Correspondence to: James C. Stegen (james.stegen@pnnl.gov)

The copyright of individual parts of the supplement might differ from the CC BY 3.0 License. 


\section{Supplemental Table and Figures}

Table S1. Soil respiration summary statistics, Matern variogram parameters, and sample sizes (n) for each season across the full, permafrost-free, and permafrost-associated spatial domains. Entries are identical to Table 1, with the addition of results from the analysis of Summer data using the reduced sampling scheme from the Fall.

5

\begin{tabular}{ccccccccc}
\hline Variable & Mean & Variance & CV (\%) & Nugget & Range & Sill & Kappa & n \\
\hline $\begin{array}{c}\text { Summer } \\
\text { (full) }\end{array}$ & 1.35 & 0.41 & 47.1 & 0.19 & 76 & 0.71 & 0.5 & 306 \\
$\begin{array}{c}\text { Reduced Summer } \\
\text { (full) }\end{array}$ & 1.36 & 0.41 & 47.0 & 0.19 & 3137 & 8 & 0.4 & 270 \\
$\begin{array}{c}\text { Fall } \\
\text { (full) }\end{array}$ & 0.60 & 0.09 & 49.8 & 0.01 & 7 & 0.07 & 0.2 & 270 \\
$\begin{array}{c}\text { Summer } \\
\text { (permafrost-free) }\end{array}$ & 1.65 & 0.39 & 37.9 & 0.22 & 133 & 0.94 & 0.3 & 156 \\
$\begin{array}{c}\text { Reduced Summer } \\
\text { (permafrost-free) }\end{array}$ & 1.66 & 0.39 & 37.6 & 0.22 & 1886 & 3.6 & 0.3 & 144 \\
$\begin{array}{c}\text { Summer } \\
\text { (permafrost) }\end{array}$ & 1.02 & 0.22 & 46.1 & 0.14 & 11 & 0.2 & 1.7 & 150 \\
\hline $\begin{array}{c}\text { Reduced Summer } \\
\text { (permafrost) }\end{array}$ & 1.01 & 0.21 & 45.7 & 0.15 & 5.5 & 0.19 & 10 & 126 \\
\hline $\begin{array}{c}\text { Fall } \\
\text { (permafrost-free) }\end{array}$ & 0.73 & 0.07 & 37.1 & 0.04 & 2.1 & 0.07 & 10 & 144 \\
\hline $\begin{array}{c}\text { Fall } \\
\text { (permafrost) }\end{array}$ & 0.43 & 0.06 & 55.7 & 0 & 2.5 & 0.05 & 0.3 & 126 \\
\hline
\end{tabular}




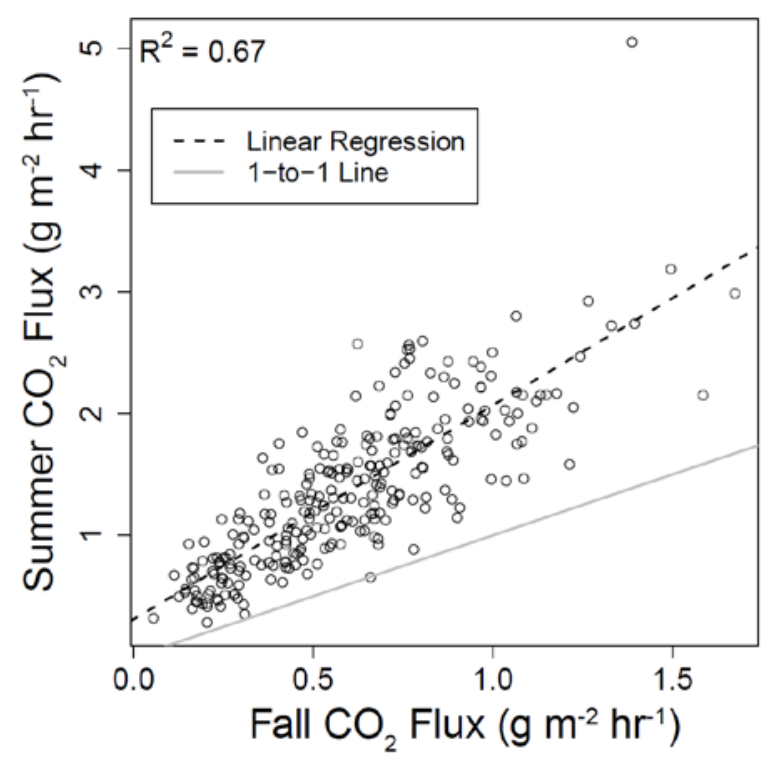

Figure S1. Relationship between Summer and Fall soil respiration. Each data point is from a given soil collar that was measured in both seasons. The linear regression and one-to-one lines are show, and the strength of the relationship is indicated by the provided $\mathrm{R}^{2}$. 

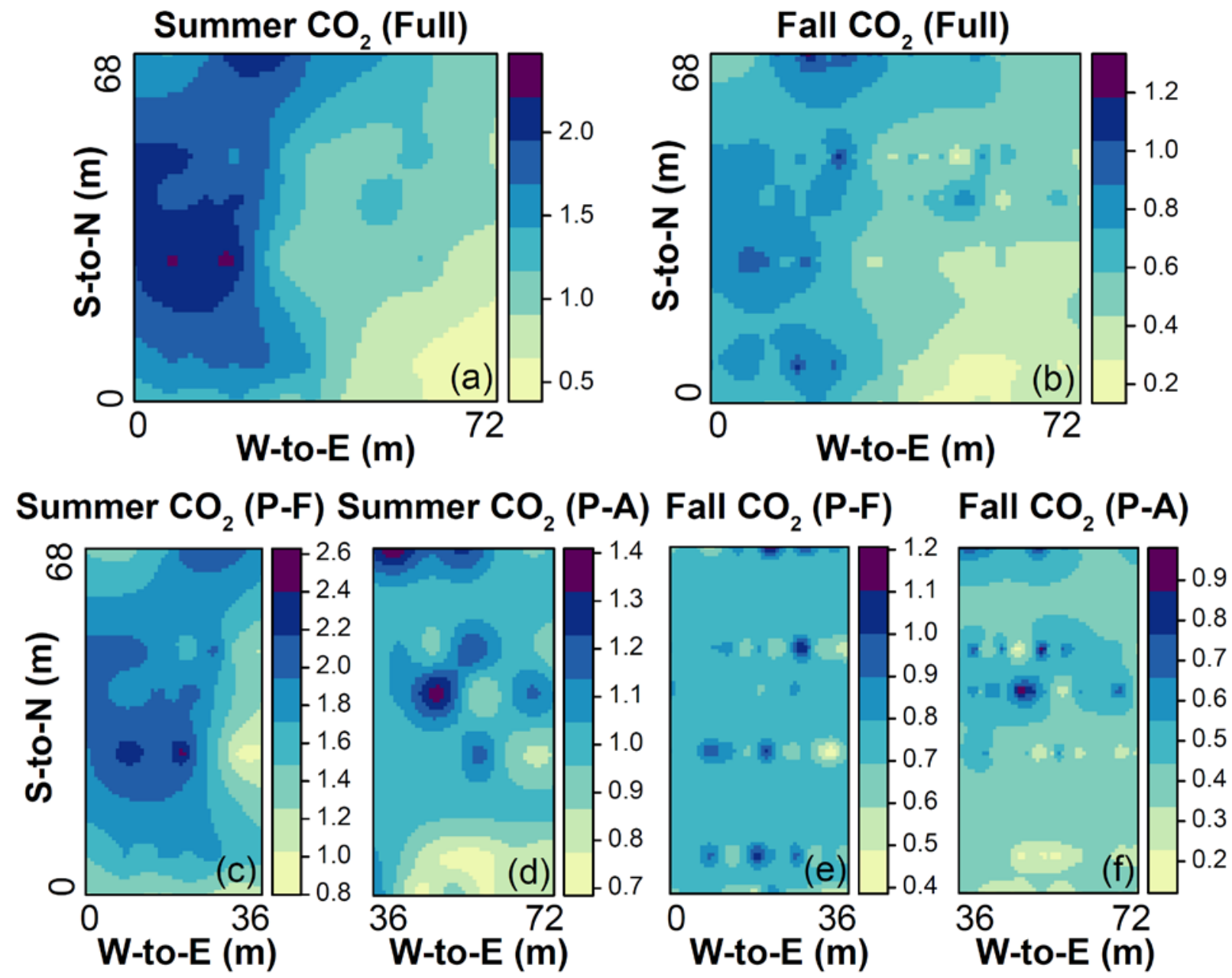

Figure S2. Interpolated soil respiration across seasons and spatial scales. Results presented for Fall are identical to Figure 5. The Summer results are based on the reduced sampling scheme used in the Fall. Each panel has its own color ramp, and in all panels the values are $\mathrm{CO}_{2}$ flux rates $\left(\mathrm{g} \mathrm{m}^{-2} \mathrm{hr}^{-1}\right)$. The vertical and horizontal axes in all panels indicate the South-to-North and

West-to-East dimensions, respectively. The top panels show interpolations across full spatial domain and the bottom panels show interpolations within the permafrost-free (P-F) and permafrost-associated (P-A) domains. Stronger spatial structure in Summer is evident as is the non-linear decline in soil respiration near $36 \mathrm{~m}$, moving from West to East; these patterns are consistent with those generated using the full Summer dataset, as shown in Figure 5. 